\title{
Detection of Mycobacterium leprae DNA by Polymerase Chain Reaction in the Blood and Nasal Secretion of Brazilian Household Contacts
}

\author{
Elza Carmen de Almeida, Alejandra Nóbrega Martinez, Viviane Câmara Maniero, \\ Ana Maria Sales, Nádia C D uppre, Euzenir Nunes Sarno, Adalberto Rezende Santos, \\ Milton 0 zório Moraes ${ }^{+}$
}

\author{
Laboratório de Hanseníase, Departmento de Medicina Tropical, Instituto Oswaldo Cruz-Fiocruz, Av. Brasil, 4365, \\ 21045-900 Manguinhos, Rio de Janeiro, RJ, Brasil
}

\begin{abstract}
DNA samples from blood and nasal swabs of 125 healthy household contacts was submitted to amplification by polymerase chain reaction (PCR) using a Mycobacterium leprae-specific sequence as a target for the detection of subclinical infection with $\mathrm{M}$. leprae. All samples were submitted to hybridization analysis in order to exclude any false positive or negative results. Two positive samples were confirmed from blood out of $119(1.7 \%)$ and two positive samples from nasal secretion out of $120(1.7 \%)$. The analysis of the families with positive individuals showed that $2.5 \%(n=3)$ of the contacts were relatives of multibacilary patients while $0.8 \%$ of the cases $(n=1)$ had a paucibacilary as an index case. All positive contacts were followed up and after one year none of them presented clinical signs of the disease. In spite of the PCR sensitivity to detect the presence of the M. leprae in a subclinical stage, this molecular approach did not seem to be a valuable tool to screen household contacts, since we determined a spurious association of the PCR positivity and further development of leprosy.
\end{abstract}

Key words: Mycobacterium leprae - polymerase chain reaction - healthy contacts - early diagnosis

Leprosy is a chronic infectious disease caused by Mycobacterium leprae. Most people within leprosy-endemic populations have been exposed to M. leprae but few develop the disease, and it seems likely that the majority of the population present genetic resistance (Feitosa et al. 1995, Santos et al. 2002, Mira et al. 2004) and develops protective immunity (Ramaprasad et al. 1997). The interruption of leprosy transmission is one of the main challenges of leprosy control programs since no consistent evidence exists that transmission has been reduced after the introduction of multidrug therapy (Buhrer-Sekula et al. 2003). Sources of infection are primarily people with high loads of bacteria with or without clinical signs of leprosy. In this regard, multibacillary (MB) patients, the main source of infection are four to 11 times more infective than a patient with paucibacillary (PB) leprosy (Noordeen et al. 1996).

Identification of $M$. leprae is difficult in part due to the inability of the leprosy bacillus to grow in vitro. The diagnosis of leprosy is based on microscopic detection of acid-fast bacilli (AFB) in tissue smears, in combination with histopathological and clinical evaluation. Because

${ }^{+}$Corresponding author. Fax: +55-21-2270.9997. E-mail: mmoraes@fiocruz.br

Received 21 January 2004

Accepted 16 June 2004 acid-fast staining requires at least $10^{4}$ organisms per gram of tissue for reliable detection (Shepard \& Docherty 1968), sensitivity is low, particularly for patients at the tuberculoid end of the leprosy spectrum when AFB are rare or absent.

A number of alternative methods for leprosy diagnosis have been proposed. Both serological tests (BuhrerSekula et al. 2003) and molecular probes (Clark-Curtiss \& Docherty 1989) have shown a certain potential for detection and identification of M. leprae in patients, but these methods suffer from, respectively, limited specificity and sensitivity.

Several investigators have used DNA amplification through the polymerase chain reaction (PCR) to amplify various genomic sequences of $M$. leprae to improve detection when low numbers of bacteria are present. Thus, PCR method for identification of the DNA, which encodes M. leprae proteins of $65 \mathrm{kDa}$ (Plikaytis et al. 1990), $18 \mathrm{kDa}$ (Williams et al. 1992) and repetitive sequences of M. leprae (Woods \& Cole 1989) was introduced as a more sensitive and specific method than the AFB examination. The number of clinical samples that can be used for PCR-mediated detection of M. leprae has increased and includes skinlymph, blood, skin and nerve biopsy, hair bulbs, and nasal secretion (Santos et al. 1999). Therefore, in this work we investigated whether M. leprae DNA from blood and nasal secretion of healthy household contacts could be detected through PCR amplification as an alternative method to prognosis and control of leprosy.

Before the study was undertaken, the contacts were informed of the purpose of the study, and written consent 
was obtained from all participants. The study was approved in Fiocruz Ethical Commitee. The household contacts of patients were defined as those persons living in the same house as the index case. The index cases from the Souza Araujo Out-Patient Unit at the Oswaldo Cruz Institute-Fiocruz in Rio de Janeiro, Brazil were clinically examined and diagnosed based on the Classification of Ridley and Jopling (Ridley \& Jopling 1966). A total of 125 healthy contacts were included in this study, 52 men and 73 women (mean age $=34 \pm 21$ years).

Blood and nasal secretion were collected from the contacts. Nasal secretion was collected on a cotton swab by gently moving the swab several times against the anterior segment of the nasal cavity. After the removal of the cotton wool, the suspension was centrifuged, and the pellet was resuspended in $40 \mu \mathrm{l}$ of TE to be frozen immediately. Before submission to PCR, samples were neutralized with of $1 \mathrm{M} \mathrm{NaH}_{2} \mathrm{PO}_{4}$ and resuspended in TE buffer as described previously (Santos et al. 1995).

Blood was withdrawn in citrate buffer by venipuncture. After separation from whole blood, peripheral blood mononuclear cells (PBMC) were also neutralized and resuspended as described above.

PCR reactions were performed as described before by Santos et al. (1993). The set of primers used was sense 5'GCACGTAAGCCTGTCGGTGG-3' and antisense 5'CGGCCGGATCCTCGATGCAC-3' according to Woods and Cole (1989). Reaction products were analyzed by $2 \%$ agarose gel electrophoresis followed by ethidium bromide staining. All negative samples were reconstituted with 100 pg of purified M. leprae DNA and submitted to another amplification to exclude the possibility of inhibition. After the exclusion of inhibited samples, all other PCR products were submitted to a southern hybridization using a ${ }^{32} \mathrm{P}-$ labeled oligonucleotide, as described before (Santos et al. 1993).

A total of 250 samples were screened for the presence of $M$. leprae DNA in both clinical specimens: blood and nasal secretion of 125 household contacts. From these contacts 75 have been in prolonged contact with leprosy patients with MB and 50 with the PB form of the disease, respectively. The inhibitory assay in negative samples demonstrated absence of PCR amplification in six (4.8\%) and five (4\%) out of 125 blood and nasal secretion samples, respectively, that were not suitable to further analysis and were excluded from the group.

After hybridization of the PCR amplified samples, two blood samples out of $119(1.7 \%)$ and other two nasal secretion samples out of $120(1.7 \%)$ showed a positive result. Other three and six samples from blood and nasal secretion, respectively, were false positives since PCR as analyzed solely by gel electrophoresis showed a positive result while the hybridization did not confirm. Three contacts tested positive related to MB $(2.5 \%)$ and one with PB $(0.8 \%)$ patients, respectively. These household contacts that tested positive did not show any clinical evidence of disease.

Over the last few years, several articles have been published on PCR-mediated amplification of M. leprae DNA and these data suggest that PCR could be a useful tool for the detection of subclinical infection with this pathogen. The upper respiratory tract is the main port of entry and exit of M. leprae and PCR-mediated detection from nasal secretion has been reported (Pattyn et al. 1993, Beyene et al. 2003). But, none of these works have consistently associated the presence of the M. leprae DNA with further development of the disease.

Individuals recorded as living in households or dwelling contacts with multibacillary patients have a higher risk of developing leprosy compared with individuals not living in such households or dwellings (Fine et al. 1997). Although residential and peri-residential contact with a multibacillary case is the strongest known determinant of leprosy risk (van Beer et al. 1999), the vast majority of such contacts never manifest disease. This indicates a crucial role for genetic factors in the establishment of $M$. leprae infection that is obviously modulated by environmental factors influencing the outcome of leprosy. Thus, the elevated risk to develop leprosy among household contact is also associated to higher exposure rate to the pathogen. So, the clear contribution of genetics and environmental factors is very difficult to define since it is impossible to separate the exposition status from the genetic background. It is estimated that 6-8\% of household contacts disclose clinical symptoms of leprosy within two years of follow-up since the diagnosis of the index case (de Matos et al. 2001). In our study, only 3.4\% showed PCR positive results in nasal secretion or blood. This low detection number of contacts in our study group could be attributed to low sensitivity of our PCR set up, concerning the very low bacterial load, if any, in the clinical specimens tested. But, this is not likely since our method for $M$. leprae detection in healthy contacts, was able to detect the bacterial DNA in at least one PB contact. Whatever the relationship between positivity of PCR and development of the disease, PCR is much more sensitive than microscopic examination for direct detection of the bacilli (Santos et al. 1993). In matter of fact, using the same PCR methodology, M. leprae DNA could be detected in blood, skin hair bulbs and nasal secretion or lymph after the completion of treatment (6 to 8 years; Santos et al. 2001). In the work presented here, four household contacts showed positivity for PCR. After a year of followup, none of them provided any evidence of clinical disease suggesting that PCR positivity might indeed represent carriage of bacilli or subclinical infection, which does not indicate by itself the evolution towards the disease.

It has been reported that household, neighbour, and social contacts respond as the major form for spreading of the disease (van Beers et al. 1999). But, as seen here, the screening by PCR to detect new cases of leprosy among contacts may not be relevant if it is used as a single test. Our group has been using PCR to solve some difficult-to-diagnose forms of leprosy such as pure neuritic leprosy where PCR proved to be a very important tool (Jardim et al. 2003). In some cases where serum and nerve biopsies were available, the serological and histopathogical examination was not clear but the PCR, in association with clinical evaluation, strongly supported the occurrence of the disease.

In summary, we conclude that PCR may not be a valuable tool for screening the household contacts in a cost- 
benefit equation. However, the association of serological tests, as suggested by others (Torres et al. 2002, Beyene et al. 2003), could improve the predictive value for PCR in leprosy diagnosis.

\section{ACKNOWLEDGMENTS}

To Denise Vieira for the collection and processing of the samples.

\section{REFERENCES}

Beyene D, Aseffa A, Harboe M, Kidane D, Macdonald M, Klatser PR, Bjune GA, Smith WC 2003. Nasal carriage of Mycobacterium leprae DNA in healthy individuals in Lega Robi village, Ethiopia. Epidemiol Infect 131: 841-848.

Buhrer-Sekula S, Smits HL, Gussenhoven GC, van Leeuwen J, Amador S, Fujiwara T, Klatser PR, Oskam L 2003. Simple and fast lateral flow test for classification of leprosy patients and identification of contacts with high risk of developing leprosy. J Clin Microbiol 41: 1991-1995.

Clark-Curtiss JE, Docherty MA 1989. A species-specific repetitive sequence in Mycobacterium leprae DNA. I Infect Dis 159: 7-15.

de Matos HJ, Duppre N, Alvim MF, MachadoVieira LM, Sarno EN, Struchiner CJ 2001. Leprosy epidemiology in a cohort of household contacts in Rio de Janeiro (1987-1991). Cad Saúde Pública 15: 533-542.

Feitosa MF, Borecki I, Krieger H, Beiguelman B, Rao DC 1995. The genetic epidemiology of leprosy in a Brazilian population. Am J Hum Genet 56: 1179-1185.

Fine PE, Sterne JA, Ponnighaus JM Bliss L, Saui J, Chihana A, Munthali M, Warndorff DK1997. Household and dwelling contact as risk factors for leprosy in northern Malawi. Am J Epidemiol 146: 91-102.

Jardim MR, Antunes SL, Santos AR, Nascimento OJ, Nery JA, Sales AM, Illarramendi X, Duppre N, Chimelli L, Sampaio EP, Sarno EP 2003. Criteria for diagnosis of pure neural leprosy. J Neurol 250: 806-809.

Mira MT, Alcais A, Van Thuc N, Moraes MO, Schurr E 2004. Susceptibility to leprosy is associated with PARK2 and PACRG. Nature 427: 636-640.

Noordeen SK, Roxas MG, Fine PE, Smith WC, Feenstra P, Gokhale SD, Joo LK, Huan-Ying L, Khalafalla G, BecxBleumink M, Srinivasan H, Rao CK, Lechat MF, Sansarricq H 1996. Eliminating leprosy as a public health problem - Is the optimism justified? World Health Forum 17: 109-144.

Pattyn SR, Ursi D, Ieven M, Grillone S, Raes V 1993. Detection of Mycobacterium leprae by the polymerase chain reaction in nasal swabs of leprosy patients and their contacts. Int J Lepr 61: 389-393.

Plikaytis BB, Gelber RH, Shinnick TM 1990. Rapid and sensi- tive detection of Mycobacterium leprae using a nested-primer gene amplification assay. J Clin Microbiol 28: 1913-1917.

Ramaprasad P, Fernando A, Madhale S, Rao JR, Edward VK, Samson PD, Klatser PR, de Wit MY, Smith WC, Cree IA 1997. Transmission and protection in leprosy: indications of the role of mucosal immunity. Lepr Rev 68: 301-315.

Ridley DS, Jopling WH 1966. Classification of leprosy according to immunity - A five group system. Int J Lepr 34: 255273.

Santos AR, Balassiano V, Oliveira ML, Pereira MA, Santos PB, Degrave WM, Suffys PN. 2001. Detection of Mycobacterium leprae DNA by polymerase chain reaction in the blood of individuals, eight years after completion of anti-leprosy therapy. Mem Inst Oswaldo Cruz 96: 1129-1133

Santos AR, Degrave WM, Suffys PN 1999. Use of polymerase chain reaction (PCR) in leprosy research. Indian J Lepr 71: 101-110.

Santos AR, de Miranda AB, Sarno EN, Suffys PN, Degrave WM 1993 Use of PCR-mediated amplification of Mycobacterium leprae DNA in different types of clinical samples for the diagnosis of leprosy. J Med Microbiol 39: 298-304.

Santos AR, Goes Filho JT, Nery JA, Duppre NC, Gallo ME, Suffys PN, Degrave WM 1995. Evaluation of PCR mediated DNA amplification in non-invasive biological specimens for subclinical detection of Mycobacterium leprae. FEMS Immunol Med Microbiol 11: 113-120.

Santos AR, Suffys PN, Vanderborght PR, Moraes MO, Vieira LM, Cabello PH, Bakker AM, Matos HJ, Huizinga TW, Ottenhoff TH, Sampaio EP, Sarno EN 2002. Role of tumor necrosis factor-alpha and interleukin-10 promoter gene polymorphisms in leprosy. J Infect Dis 86: 1687-1691.

Shepard CC, McRae DH 1968. A method for counting acid-fast bacteria. Int J Lepr 36: 78-82.

Torres P, Camarena JJ, Gomez JR, Nogueira JM, Gimeno V, Navarro JC, Olmos A 2003 Comparison of PCR mediated amplification of DNA and the classical methods for detection of Mycobacterium leprae in different types of clinical samples in leprosy patients and contacts. Lepr Rev 74: 1830.

van Beers SM, Hatta M, Klatser PR. 1999. Patient contact is the major determinant in incident leprosy: implications for future control. Int J Lepr 67: 119-128

Williams DL, Gillis TP, Booth RJ, Looker D, Watson JD 1992. The use of a specific DNA probe and polymerase chain reaction for the detection of Mycobacterium leprae. J Infect Dis 162: 193-200.

Woods SA, Cole ST 1989. A rapid method for the detection of potentially viable Mycobacterium leprae in human biopsies: a novel application of PCR. FEMS Microbiol Lett 53: 305-309. 
